\title{
Matrix: las claves de un relato prometeico y mesiánico
}

\author{
Chantal Martínez Femández
}

Matrix (The Matrix, Andy y Larry Wachowski, 1999), revolucionó la historia del cine con unos espectaculares efectos especiales. El presente estudio se centra, sin embargo, en su argumento lleno de alusiones a la religión, la mitología, la filosofía, la literatura y el arte. $Y$ aunque la película supone un auténtico alarde a la postmodernidad, y por tanto, al eclecticismo y el pastiche, su guión no está exento de valor y originalidad.

The Matrix (Andy y Larry Wachowski, 1999), revolutionized the history of cinema with its spectactular special effects. Nevertheless, this study focuses on a plot full of allusions to religion, mythology, phylosophy and art. Although the film is a tribute to postmodernism and, by the same token, to the eclectic and pastiche, the screenplay is not short on courage or originality.

Matrix es la historia de un mundo dominado por la máquina, un mundo en el cual el hombre es el instrumento de la terrible precisión maquinista. En Matrix el ser humano vive sin conocer esta escalofriante realidad inmerso en un mundo creado y compuesto por la Inteligencia Artificial (A.l.: Artificial Intelligence) para ocultar su verdadera identidad como mera fuente de energía, como esclavo. Sin embargo, dentro de este caótico panorama un grupo de rebeldes liderados por Morfeo (Laurence Fishburne) son entrenados para destruir Matrix y liberar al hombre de su cautiverio. En el seno de esta resistencia late la esperanza de encontrar al Elegido, a un nuevo Mesías cuya misión será despertar a la raza humana de su letargo y hacer que tome de nuevo las riendas de su existencia. Morfeo cree ciegamente que este salvador es Neo (Keanu Reeves), un joven pirata informático que siempre ha tenido la certeza de que tras la "realidad" había algo más, de su fe en sí mismo dependerá que se convierta o no en ese esperado libertador. Dentro del grupo de resistencia se encuentra Trinity (Carrie-Anne Moss) que será la primera que comenzará a dar respuestas a las preguntas que Neo guarda dentro de sí, Trinity esconde un importante secreto: su destino es amar al Elegido. También forma parte

MARTÍNEZ FERNÁNDEZ, ChantaI: "Matrix: las claves de un relato prometeico y mesiánico", en Boletín de Arte n² 24, Universidad de Málaga, 2003, págs. 393-422. 
del grupo Cifra (Joe Pantoliano) que, seducido por las comodidades materiales de Matrix, traicionará a Morfeo y a sus compañeros a cambio de una existencia tranquila como un humano más. Neo deberá salvar a Morfeo y autoconcienciarse de su "divina misión" lo que le conducirá, tras una mesiánica muerte y resurrección, a la liberación de la humanidad.

Matrix es la segunda película, tras Lazos ardientes (Bound, 1996), de los hermanos Larry y Andy Wachowski que trabajaron como asesores de la editorial Marvel y cuyo ambicioso proyecto comenzaron en 1997 con la realización de un guión de más de 400 páginas que fueron ilustradas por Steve Skroce, creador de Spider-man y Wolverine, y otro de los grandes dibujantes de la Marvel, Geof Darrow. En este libro, a modo de un gran story-board, aparece explicada e ilustrada toda la puesta en escena original de Matrix; algunas escenas fueron suprimidas por cuestión de tiempo pero los hermanos Wachowski quisieron que el proyecto original se respetase lo máximo posible ${ }^{1}$. Así pues, Matrix es en esencia un gran cómic de atractivas imágenes y estética cibernética, de hecho, para los Wachowski, cómic y cine comparten una misma esencia diferenciándose únicamente por la existencia o no de movimiento. Esta concepción cinematográfica queda patente tanto en el storyboard como en el resultado final, y es que en pocas ocasiones ha sido tan fiel la puesta en escena de una película a la idea original de sus guionistas. En Matrix cobran gran protagonismo unos efectos especiales impresionantes hasta el punto de ser calificada como "la primera película del siglo XXI". No obstante, y aunque el estudio de sus revolucionarios medios podría configurar en sí mismo un trabajo amplio e interesante, nos centraremos en su argumento lleno de alusiones e influencias que producen un resultado absolutamente ecléctico. Hemos intentado llevar a cabo un estudio lo más exhaustivo posible, manejando una gran variedad de fuentes; sin embargo, no caeremos en un excesivo intelectualismo. No obstante, hay que tener en cuenta que en Matrix, aunque se citan o esbozan claras alusiones a la religión, la filosofía o el arte, no se profundiza en ellas: recordemos que, por muy rico que sea su argumento, estamos ante un ejemplo clarísimo de postmodernidad cinematográfica $y$, por tanto, de hibridación y pastiche.

A pesar de que el desarrollo de la idea de los hermanos Wachowski se limitaba exclusivamente a una sola película, la acogida por parte del público sorprendió a estos creadores convirtiendo su obra, no sólo en un gran éxito de taquilla sino en una verdadera película de culto con millones de seguidores en todo el mundo. En este año 2003 se estrenan las dos esperadas secuelas: Matrix Reloaded y Matrix Revolutions. De este modo, ya tenemos una trilogía completa y, por tanto, el universo de Matrix se cierra poniendo fin a la incógnita que nos plantearon los Wachowski al final de su primera película. Además, la versión animada, Animatrix, ya circula por

\footnotetext{
${ }^{1}$ Algunas de las ilustraciones de este trabajo pertenecen a ese magnífico story-board, hemos querido mostrar así su calidad y perfección técnica.
} 
Internet y uno de los nueve cortos que la componen, El último vuelo de Osiris, puede verse en los cines. Animatrix se comercializará próximamente en DVD, en ella se narran sucesos no conocidos o pasajes que no quedaron demasiado claros en la película original a la vez que nos aporta más datos sobre la vida de cada uno de los protagonistas. Esta historia animada lleva la firma de algunos de los estudios más prestigiosos del mundo como Madhouse, y para realizarla se han utilizado desde las técnicas tradicionales de animación hasta los procesos 3-D más sofisticados.

Los hermanos Wachowski son conscientes de la presencia de la mitología y las antiguas leyendas en la cultura actual. Así vemos como en la historia de Matrix se entremezclan referencias religiosas al Apocalipsis o (Libro de las Revelaciones), la mitología griega, la cultura babilónica, el cristianismo e incluso el mundo de fantasía de Lewis Carrol en Alicia en el país de las maravillas². Quizás el tema más evidente es el de la llegada de un Mesías que debe salvar al mundo violentando un orden establecido para cambiar una situación impuesta injustamente y que, llegando al extremo del relato mesiánico, pasa por el autosacrificio redentor. Éste es uno de los veintiún argumentos universales del cine que revisan Jordi Balló y Xavier Pérez en su magnífico estudio La semilla inmortaß.

\section{UN NUEVO MESIAS PARA SALVAR A LA HUMANIDAD}

La base del relato mesiánico es la necesidad de un líder por parte de una comunidad en crisis, un grupo que mantiene vivo el recuerdo de una época mejor y cuyo orden quieren restablecer gracias a la intercesión de este Elegido. Esta comunidad se enfrenta a un cambio que es traumático pero también enriquecedor a nivel personal y colectivo, tanto más para los miembros que, por alguna razón, se hallan más cercanos al Mesías. En Matrix encontramos todos los ingredientes del relato mesiánico: una sociedad en crisis dominada y oprimida por la Inteligencia Artificial, un grupo de rebeldes que luchan contra este orden establecido, un joven Elegido para cambiar el mundo y hasta un "judas" traidor.

La figura de Neo (FIG. 1) sufrirá una transformación a lo largo de la historia: en un primer momento es Thomas A. Anderson, un joven programador que trabaja en una gran empresa de software y al cual le cuesta adaptarse a las rígidas normas hasta el punto de ser advertido por el director de que lo despedirá si no se ajusta a un

\footnotetext{
${ }^{2}$ Martin Gardnex, que habfa revolucionado el mundo de la realidad virtual creando un juego de simulación al que llamó "El Juego de la Vida", habla de los lazos que unen los mundos imaginarios de Lewis Carrol y los mundos generados por ordenador. De hecho, anotaba todas sus observaciones en un cuaderno al que llamó Annoted Alicia (Comentarios sobre Alicia). WOOLLEY, B.: El Universo virtual, Madrid, Acento, 1994, pág. 68.

${ }^{3}$ BALLÓ, J. y PÉREZ, X.: La semilla inmortal. Los argumentos universales en el cine, Barcelona, Anagrama, 1997.
} 


\section{Neo, un Mesias para salvar a la Humanidad del poder de la Inteligencia Artificial}

inflexible horario y disciplina. El hombre como un eslabón más de una cadena, de un sistema inmovilista, explotador y opresivo es una idea que, desde el socialismo utópico de Fourier y Saint Simon hasta las teorías marxistas, se ha mantenido viva y que fue retomada de forma magnífica por Fritz Lang en Metrópolis (1926) $)^{4}$. Esta película

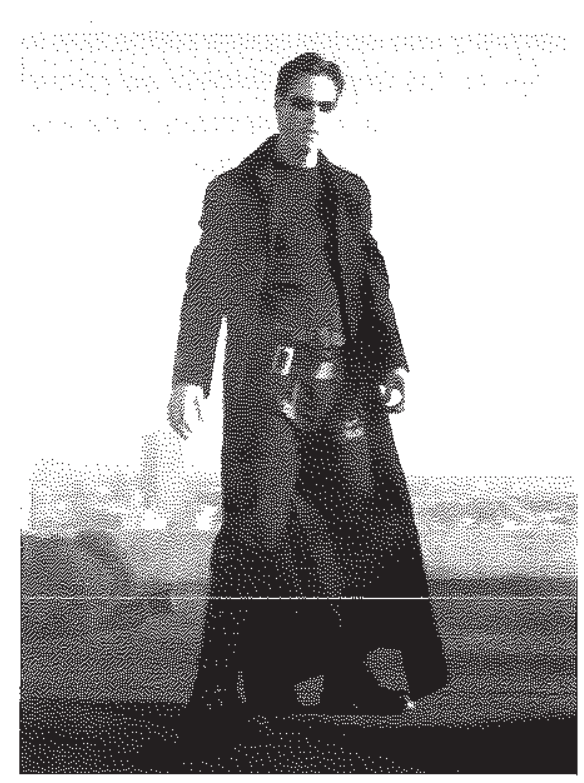
muestra la ciudad del futuro sometida a una marcada jerarquización: dominadores arriba y dominados abajo.

Evadiéndose de este terrible y férreo control, Anderson en su tiempo libre se convierte en un pirata informático que responde al nombre de $\mathrm{Neo}$, siendo éste su verdadero "Yo". En esta otra dimensión de su existencia, Neo se encuentra atormentado por la sospecha de que tras el mundo que le rodea hay algo más y, aunque no sabe lo que es, vive atormentado por una pregunta que le viene una y otra vez a la mente: ¿qué es Matrix?. Esta cuestión sólo será aclarada cuando Morfeo contacte con él y le de las respuestas que necesita.

Como en todo relato mesiánico, Neo pasa por una serie de fases que son, en definitiva, las que hacen avanzar la historia. Un primer periodo seria la formación y el entrenamiento por medio de sofisticados programas informáticos de lucha, salto, etc.(FiG. 2). Sin embargo, más importante y quizás el auténtico motor de la historia, sea la toma de conciencia de Neo de su misión trascendente. Debemos aclarar que el nombre de Neo no sólo hace alusión al concepto de "nuevo"; si cambiamos el orden de sus letras el resultado es la palabra "One", es decir, que Neo es el Primero, la Unidad. Sin embargo, el autoconvencimiento de su verdadera capacidad va en Matrix más alıá que en otras historias de este tipo, y es que Neo no sólo debe tomar

\footnotetext{
${ }^{4}$ De hecho, Lang está más interesado y fascinado por las máquinas que por los seres humanos . recordar que los obreros se mueven sincronizadamente con pequeños pasitos mecánicos. CASTRO, A.: "Metrópolis de Fritz Lang", Dirigido por. Revista de cine, n² 279, Barcelona, 1999, pág. 53.
} 


Q - Matrix: las claves de un relato prometeico mesiánico

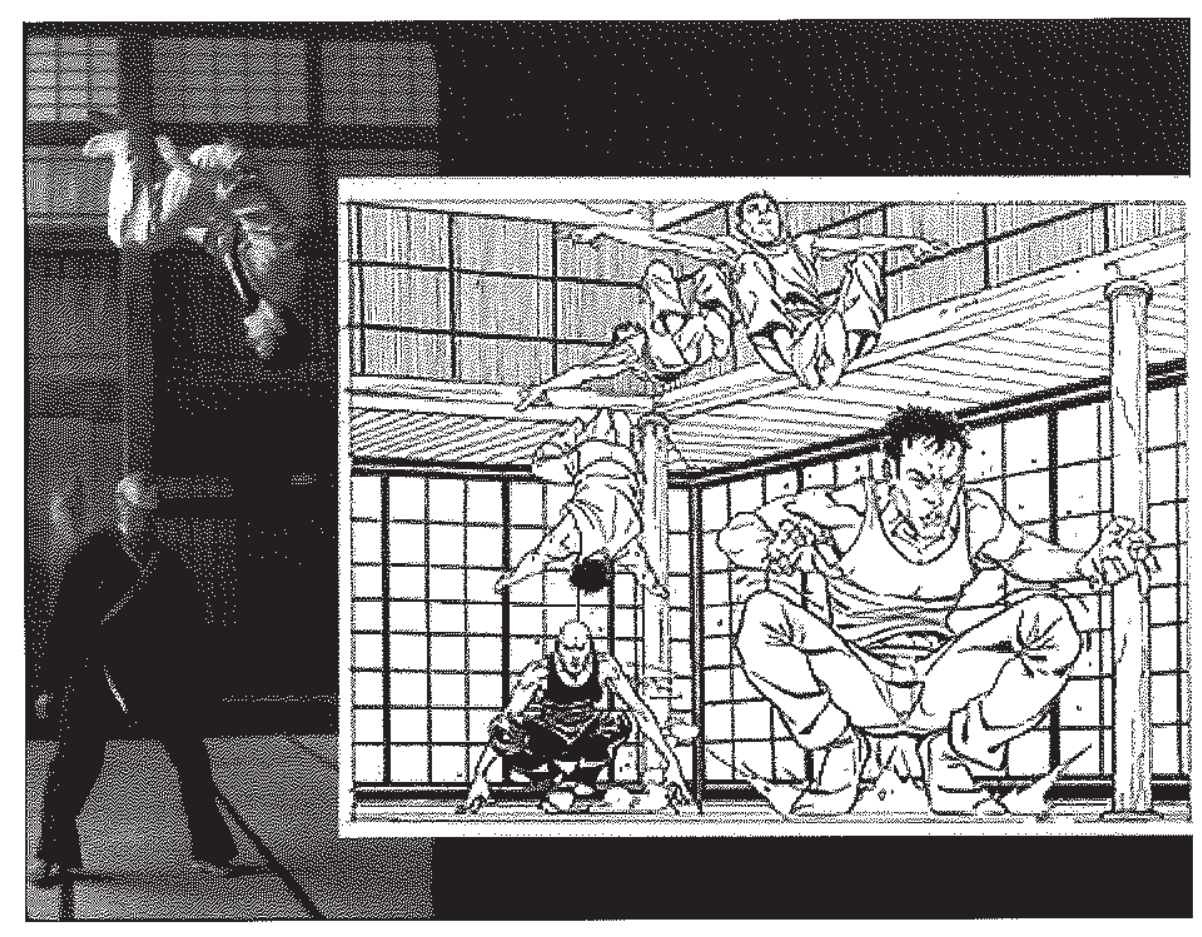

2. Comparación entre el story-board (DARROW y SKROCE) y el fotograma donde Neo es entrenado por Morfeo a través de un programa informático

conciencia de su enorme potencial "divino", sino que además debe creer la oscura y, valga la redundancia, increíble verdad: el mundo en el que ha vivido siempre no existe, es sólo una imagen creada por la Inteligencia Artificial, que es la que ahora tiene el poder y emplea al hombre como fuente de energía cultivándolo en extensas plantaciones de humanos. Hasta el estreno del film, la Inteligencia Artificial jamás habia sido presentada bajo una óptica tan terrorífica, investida de atributos demiúrgicos ${ }^{5}$.

Uno de los momentos cumbre y, sin duda, de más impacto emocional para el espectador, es la localización del cuerpo de Neo dentro de esas terribles plantas de cultivo para ser desconectado y liberado. A esta escena le suceden una serie de planos encadenados mediante fundidos en negro en los cuales el cuerpo del protagonista va siendo reanimado: se trata de un cuerpo que jamás ha utilizado, de

${ }^{5}$ FERNÁNDEZ VALENTÍ, T. y NAVARRO, A. J.: "Seres de Metal. La robótica en el cine", Dirigido por. Revista de cine, no 301, Barcelona, 2001, pág. 58. 


\section{Darrow y Skroce: "Matrix} te posee"

modo que todos sus músculos y sentidos se encuentran atrofiados. Luego, cuando Morfeo le desvela a Neo toda esta verdad y le muestra en una pantalla de televisión los campos donde el hombre es cultivado, licuando a los muertos y dándoselo por vía intravenosa a los recién nacidos, el protagonista no da crédito a lo que ve. Matrix es un sistema, es "la matriz" que alberga y maneja a la humanidad, pero la mayoría de los humanos no están

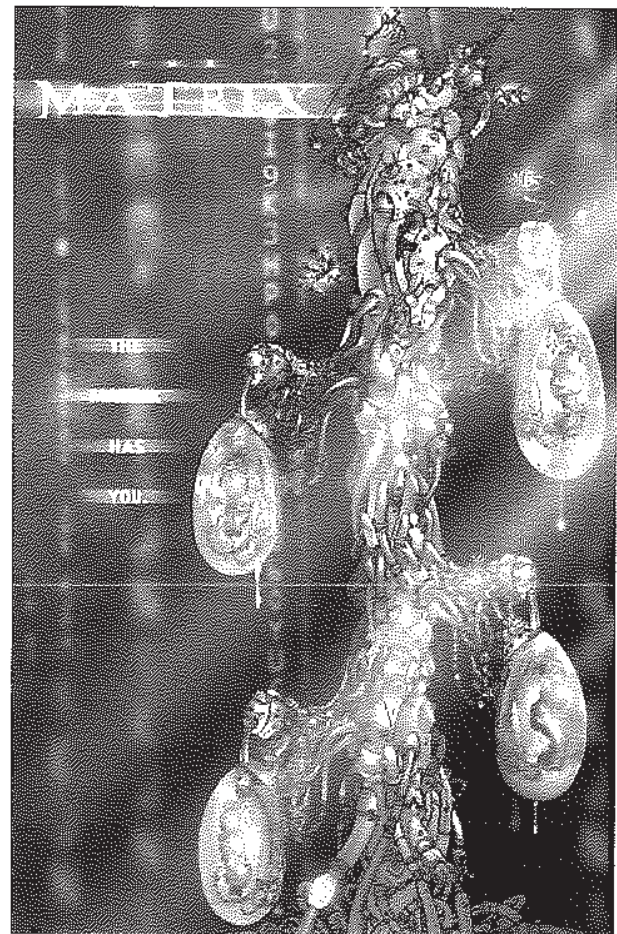
preparados para despertar (FG. 3).

Tan increíble es la auténtica realidad que incluso a Neo (el supuesto Mesías) le resulta inconcebible. Esta realidad caótica que se nos presenta en Matrix no está, sín embargo, lejos de los últimos avances de la macrofísica, ya que esta ciencia concibe la "desmaterialización" en la escala del mundo tal y como lo perciben los sentidos, de modo que el impacto de las nuevas tecnologías llevaría a un progresivo rebajamiento de la materialidad del mundo, o lo que es lo mismo, se produciria una contracción del universo de los objetos materiales, objetos que serian sustituidos por procesos y servicios cada vez más inmateriales ${ }^{6}$.

Una vez en el mundo "real", los miembros del grupo pueden entrar y salir de Matrix cuando quieran mediante un teléfono (elemento clave del atrezzo, vehículo de entrada y salida de Matrix) que esté conectado al ordenador central del sistema. Una vez allí todo es posible: saltar de edíficio en edificio, dominar a la perfección todos los estilos de lucha posibles e incluso esquivar las balas. Se trata de liberar la mente de miedos y dudas y de las normales limitaciones humanas. Ésto será lo que deberá conseguir Morfeo de Neo que, no olvidemos, ha vivido toda su vida inmerso en este mundo proyectado como un humano más preso del sistema.

"MALDONADO, T.: Lo real y lo virtual, Barcelona, Gedisa, 1994, pág. 13. 
El Oráculo juega un papel primordial en el desarrollo de la historia, particularmente en el autoconvencimiento de Neo de su misión trascendental, y es que, contrariamente a lo que cabía suponer, le dice a Neo que él no es el Elegido puesto que parece esperar algo, pero también le advierte de que tendrá que elegir entre su vida o la de Morfeo llegado el momento. El Oráculo supone una clarísima referencia al mundo clásico: basta nombrar al Oráculo de Delfos que vaticinó el futuro de todos los héroes desde Hércules a Jasón. Sin embargo, lo que nos sorprende del tratamiento que este "lugar sagrado" recibe en Matrix, es que no se trata de un suntuoso templo donde una enigmática pitonisa acoge a los visitantes. Nuestro Oráculo es un simple apartamento donde habitan los nuevos potenciales, un grupo de niños que conocen la realidad de Matrix y ésto les permite manipularla a su antojo moviendo objetos en el aire o doblando cucharas con la mente. La pitonisa (Gloria Foster) es una mujer madura de color, un ama de casa más que, cuando llega $\mathrm{Neo}^{7}$, se encuentra horneando una bandeja con galletas. No obstante, sobre la puerta de la cocina hay un cartel en el cual vemos escrita la frase NOSCE TE IPSUM. La mujer le sugiere a Neo que la lea y le dice lo que significa: "Conócete a ti mismo". Éste era el lema que se podía leer, según la mitología griega, en la entrada del santuario de Apolo de Delfos.

Lo cierto es que el vaticinio del Oráculo supone para Neo una gran desilusión, pero no por sí mismo que nunca ha estado muy seguro de su poder, sino por lo que significará para Morfeo que tan ciegamente cree en él. Sin embargo, la captura de su mentor por parte de los agentes pondrá en evidencia que el Oráculo tenía razón y será el motor que impulse a Neo a dar su vida por la de su amigo, el aliciente que necesita para creer en sí mismo. Asistimos, de este modo, a la idea de un sacrificio personal por un bien mayor. Sobran las aclaraciones sobre las similitudes entre la figura de Neo y la de Jesucristo, tanto más si tenemos en cuenta que tras esta muerte se produce una triunfal resurrección que marcará el comienzo de una nueva era para la humanidad.

Tras ser brutalmente abatido a balas por el agente Smith (Hugo Weaving), Neo se levanta con una fuerza y un poder nuevos y, convertido ya en el auténtico Salvador, es capaz de ver Matrix tal y como es en realidad: un código cifrado digital, un sistema informático ( $F(G, 4)$. Ahora Neo puede ser más rápido incluso que las balas que los agentes disparan contra él en una de las escenas más espectaculares de la película donde, en su trayectoria por el aire, las balas describen una estela ondulada hasta llegar a Neo ante el cual se detienen y caen al suelo. Tras entrar en el cuerpo del agente Smith y romperlo como de de un cristal se tratase (recordemos que ahora Neo tiene un poder ilimitado y que los agentes no son "reales" sino meros sistemas

\footnotetext{
${ }^{7}$ Lo cierto es que el joven se muestra cauteloso y bastante desconfiado durante esta visita. Recordemos que acaba de descubrir "la verdad" de manos de Morfeo y el impacto ha sido enorme. Además, no cree ser el Elegido que tanto desea el grupo.
} 


Q:- Vhantal Martinez Fernández

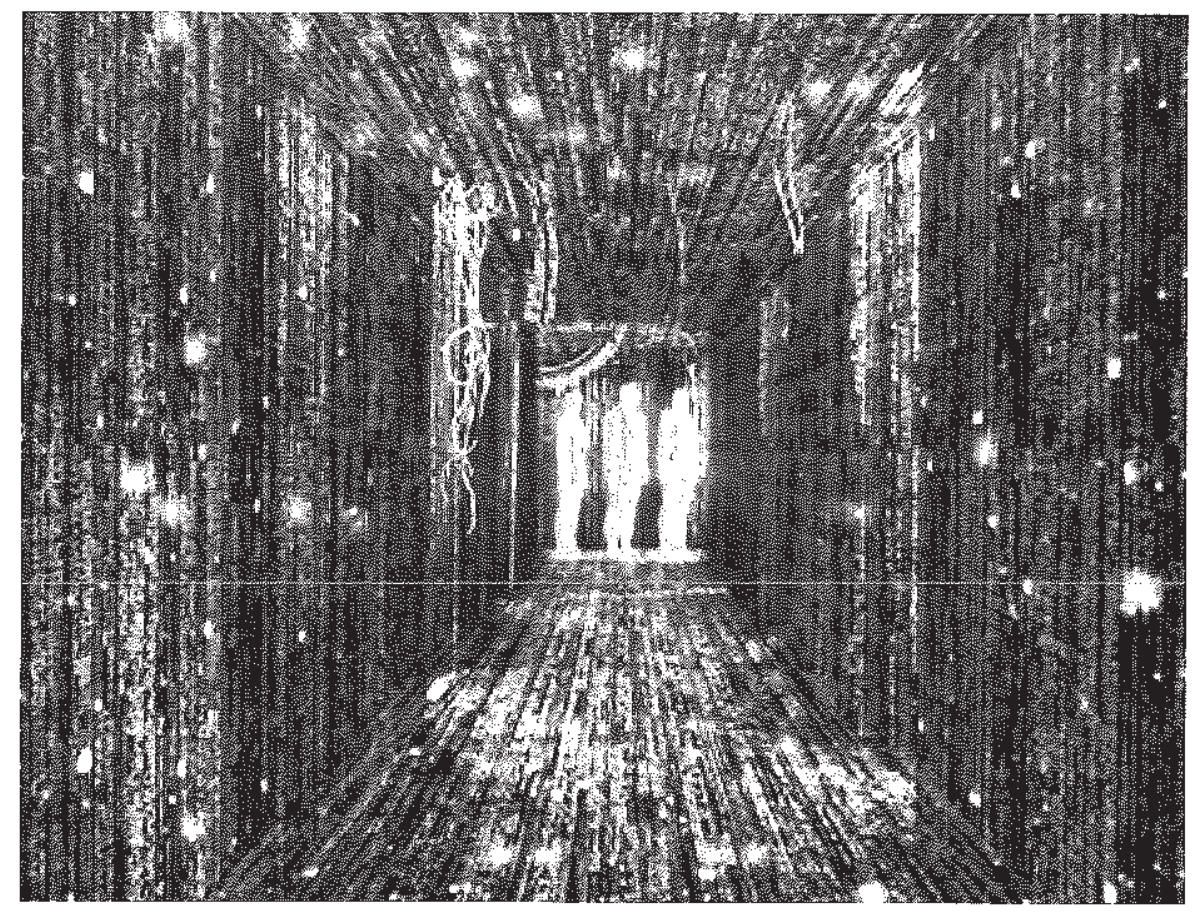

4. La "realidad" tal y como es en Matrix; un código cifrado digital

de Matrix), los otros dos agentes huyen. Inmediatamente, Neo vuelve a la nave que está siendo atacada por centinelas y donde se encuentran Trinity, Tanque y Morfeo, los únicos supervivientes del grupo. Aunque ya ha pasado el peligro y la aventura parece haber terminado, la misión de nuestros héroes debe continuar pues en sus manos está la liberación de la humanidad, a pesar de que la tarea es difícil, cuentan con la ayuda del Mesias reencontrado.

Si hasta ahora la "divinidad" de Neo se ha mostrado humanizada por sus dudas y su lucha interior, en la última escena de la película aparece como un auténtico superhéroe que, tras advertir desde una cabina (de nuevo el teléfono) a la humanidad de su cometido, sale volando sobre los edificios de la ciudad en una clara alusión a los típicos superhéroes del mundo del cómic que también tienen una misión mesiánica. Quizás la más clara influencia es la de Supermán: creado por Jerry Siegel y Joe Schuster, fue llevado al cine por primera vez por Richard Donner (Superman, 1978) ${ }^{8}$, donde un formal Clark Kent se transformaba en superhombre dentro de una cabina telefónica. 


\section{Critievilos Matrix: las claves de un relato prometeico mesiánico}

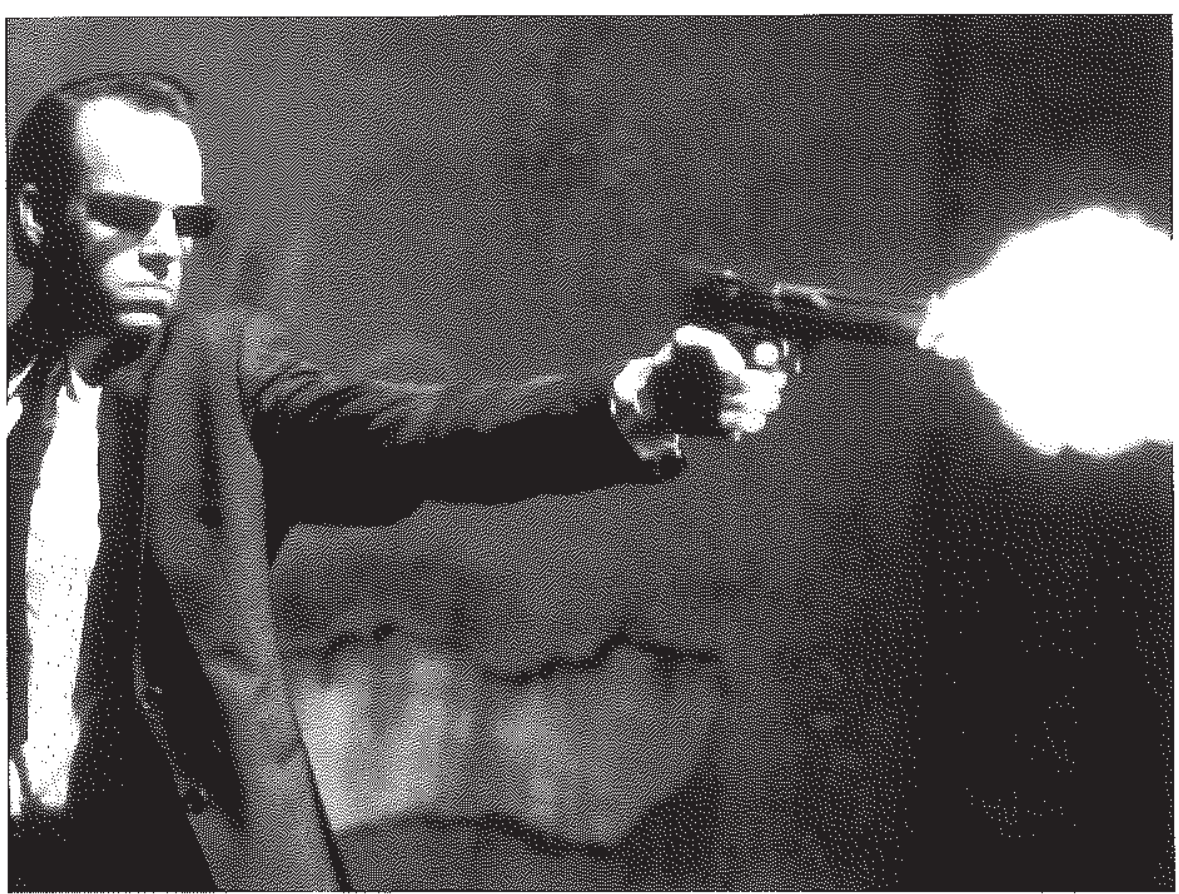

5. El temible agente Smith vela por el orden de Matrix

\section{OTROS PERSONAJES:}

\section{LOS AGENTES, EL MENTOR Y LA HEROÍNA}

Si de superpoderes y capacidades excepcionales se habla, no podemos dejar de nombrar a los agentes (FiG. 5), sin duda un peligro inminente para los compañeros de Morfeo pues son los vigilantes del sistema, su misión es velar por el orden de Matrix $y$, por supuesto, acabar con todo aquello que lo altere. Los agentes son programas capaces de sentir, tienen la capacidad de entrar y salir de Matrix a su antojo desde cualquier software que esté integrado en su sistema, asi que pueden adoptar la forma de cualquier humano u objeto. Su energía y velocidad están basadas en un mundo de reglas que es, en definitiva, lo que es Matrix: una realidad fríamente calculada y

${ }^{8}$ A esta primera parte le sucederían tres más, no tan afortunadas. Aunque la segunda parte no carecía de cierto encanto, la última (Superman $N$ ) dirigida en 1987 por Sidney J. Furie, fue un auténtico fracaso. 
medida. En el film sólo vemos a tres de estos agentes, el principal, Smith, se convierte en un auténtico rival para Neo. La imagen de estos agentes es hierática, esconden su mirada tras unas gafas negras y van elegantemente ataviados con un traje de chaqueta oscuro, camisa blanca y corbata. Esta estética fría alude directamente a las ideas de uniformidad y repetición seriada, pero también está muy cerca del look de Quentin Tarantino. Las escenas que protagonizan y en las que se baten a duelo con Neo (verdaderas citas al western cinematográfico), son quizás las más espectaculares de la película.

Smith está obsesionado con la idea de destruir la ciudad de Zion ${ }^{9}$, último reducto donde los humanos nacen libres del alcance de Matrix. Para este gélido agente, la raza humana es un auténtico virus y su labor es erradicarlo, por lo que no es extraño que quiera destruir este útimo refugio auténticamente humano ubicado cerca del núcleo terrestre. El nombre de esta última ciudad libre de nuevo nos pone en la pista de una referencia mítica, pues según el Antiguo Testamento Sión (Yabal Sahyün en árabe), era una de las colinas sobre las que se edificó Jerusalén. Este nombre daría lugar al de sionismo como movimiento a favor de la creación de un estado israeli en Palestina. De este modo, la historia real funciona como inspiración para la ficción: los rebeldes, partiendo de Zión, quieren crear un planeta libre del control de las máquinas.

Ya hemos hablado de las múltiples influencias de la mitología clásica en esta película, una de las alusiones más claras es la existencia de un Oráculo, sin embargo, también podemos hablar a este respecto de la figura de Morfeo (FiG. 6) cuyo nombre corresponde al dios de los sueños hijo de la Noche y el Sueño, y cuya naturaleza le permitía adoptar forma humana (Morfeo proviene del griego morpheque significa forma) para despertar a las personas dormidas. $Y$ es que el personaje de Fishburne no podía responder a otro nombre pues su misión es precisamente esa: despertar a los humanos sumidos en un profundo letargo y hacer que recuperen la conciencia para luchar contra el terrible poder que los domina. La razón de su vida es buscar al Elegido, movido por una fe ciega en un futuro mejor, es él quien encuentra a Neo y lo instruye para que tome las riendas de su vida y se consciencie de su enorme potencial. A pesar de las dudas del resto del grupo y del propio Neo, sólo Morfeo y Trinity creen desde un principio en el nuevo Salvador; el primero por su esperanza de cambio y la joven por el amor que siente por él. Morfeo es un hombre especial que, desde un principio (su primera aparición es en su encuentro con Neo en el acogedor salón de un antiguo edificio), despierta la confianza y la admiración del protagonista. En esta primera toma de contacto, Morfeo le da a elegir a Neo entre

\footnotetext{
${ }^{9}$ Puede aparecer también como Xión o Sión, sin embargo, en la mayoría de los casos aparece escrita con " $z$ ". Este reducto humano libre del control de la Inteligencia Artificial, jugará un papel fundamental en el desarrollo de las dos últimas entregas de la trilogía (Matrix Reloaded y Matrix Revolutions).
} 
6. Morfeo, lider del grupo rebelde y mentor de Neo

dos pildoras: la azul supone seguir viviendo en Matrix ajeno a la "realidad", la roja10 (la que elige, claro está, el protagonista) significa renunciar a una vida simulada virtualmente para luchar contra el sistema opresor.

Morfeo es el comandante de la nave "Nabucodonosor" (clara alusión histórica y mítica al rey babilónico) y el cabecilla de los rebeldes. No sabemos mucho de su vida y es, quizás, este misterio lo que hace más atractiva su figura. Sin embargo, él mismo le narra a Neo en la nave que existió una vez un hombre capaz de cambiar el rumbo fatídico del mundo, el cual le dijo que nacería en el seno de Matrix un nuevo Mesías capaz de acabar definitivamente con este terrible control. Desde entonces la vida de Morfeo ha consistido en la búsqueda incesante del salvador de la humanidad. El líder del grupo es representado como un hombre de color joven y atractivo, siempre ataviado con un largo abrigo negro y con unas minúsculas gafas con cristales de espejo, su serena expresión rebosa inteligencia y elocuencia de modo que desde un principio sus dotes de maestro y mentor son evidentes.

Si es Morfeo quien, alentado por una fe ciega, busca y contacta con Neo cuando éste está aún inmerso en Matrix como Thomas A. Anderson, es Trinity el primer punto de contacto del joven con el grupo. La imagen de esta heroína es la de una mujer independiente y fuerte, quizás el miembro del grupo en el cual Morfeo deposita más confianza, de hecho, es el oficial primero de su nave. Su rostro hierático y su

\footnotetext{
${ }^{10}$ El rojo es, sin duda, un color mucho más llamativo y atrayente que el frío azul. Sin embargo, también hay en esta secuencia un claro simbolismo de los colores: el rojo es el color de la lucha y de la revolución. Y precisamente una revolución es lo que acepta Neo al tomarse la píldora, una dura lucha para derrotar a la Máquina y recuperar la libertad. Sobre el simbolismo de los colores destaca el estudio BRUSATIN, M.: Historia de los colores, Barcelona, Paidós, 1987.
} 
aparente frialdad esconden un secreto que, ya hemos mencionado, y que es vital para comprender la identidad de Neo: Trinity sabe por el Oráculo que se va a enamorar del Elegido, por eso intuímos desde el principio que, a pesar de las dudas y de que Neo se nos muestre sin atisbo alguno de "divinidad", va a resultar ser el Mesías. No obstante, a lo largo de la historia se nos dan algunas pistas sobre la posible naturaleza de Neo. Una de ellas, quizás la más briliante, se produce cuando uno de los clientes de Neo (en su faceta de pirata informático) acude a su apartamento para que le entregue un diskette que le había encargado, cuando Neo le entrega la mercancía su amigo le responde en señal de agradecimiento "Eres mi Jesucristo particular". Poco después se producirá el primer acercamiento entre Trinity y Neo en una discoteca donde nuestro protagonista acude alentado por un conejo blanco que lleva tatuado una de las chicas que acompañaban a su cliente. En un contacto anterior, Morfeo le había dicho que siguiera al conejo blanco en un clarísimo guiño a la historia de Alicia en el país de las Maravillas de Lewis Carroll. Este primer encuentro entre los dos jóvenes evidencia ya la atracción que se producirá entre ellos quizás por el nerviosismo que demuestra Neo cuando Trinity se le aproxima y comienza a hablarle en el oído. Será en este momento cuando Neo le plantee la pregunta que lo atormenta: ¿qué es Matrix?. Con su misterio característico, la joven le dirá que ella también buscaba algo y que él (Morfeo) la encontró como también lo encontrará a él para liberarlo.

El nombre de la protagonista femenina de esa historia nos remite, de nuevo, al Cristianismo pues Trinity significa Trinidad o, lo que es lo mismo, la unión entre el Hombre, Dios y el Espíritu. Es decir, que Trinity representaría al espíritu cerrando ef triángulo junto a Neo —el hombre - y Morfeo — mentor, equivalente a Dios en esta historia - La imagen de Trinity está muy clara desde el principio de la historia, pues su primera aparición coincide con la primera escena de la película. La joven se encuentra intentando conectar con Neo desde un ordenador de la red general de Matrix mientras habla a través de un teléfono móvil con Cifra (Joe Pantoliano) y le pregunta si la línea está protegida a lo que su compañero responde que sí. Sin embargo, Trinity es inmediatamente sorprendida por la policia con lo que ya podemos sospechar que Cifra no es totalmente honesto (más tarde descubriremos su traición a Morfeo y al resto del grupo). Cuando la policía arresta a Trinity dentro del edificio llegan también los terribles agentes, los auténticos vigilantes del orden en Matrix, pues conocen a la "delincuente" y saben que no es una humana cualquiera. Trinity no tardará en desplegar sus asombrosas estrategias de lucha para librarse de los policias (FiG. 7), y asi, cuando los agentes entran en el edificio Trinity ya ha huido en una impresionante carrera por los tejados de la ciudad.

Esta huida, llena de saltos imposibles de edificio en edificio (FG. 8), nos introduce en el increible mundo de ficción de la película, en una realidad sin límites. Esta persecución por los tejados de una oscura ciudad tiene su más claro antecedente en El Cuervo (The Crow, Alex Proyas, 1994), cuyo director trabajó en el equipo de producción de Matrix y cuyas influencias son claras en muchas escenas. Y es que la 


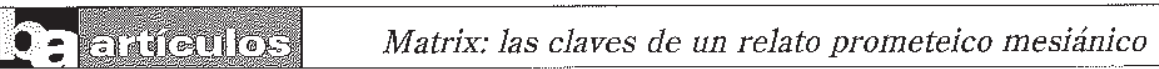

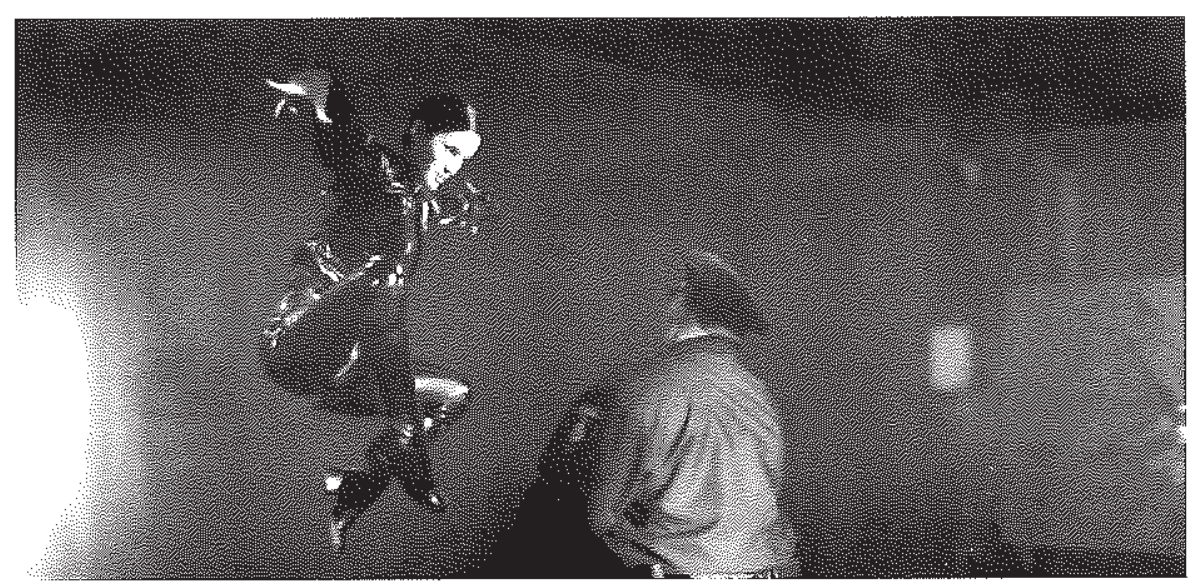

7. Trinity desplegando sus artes de lucha

negra y ágil figura de Trinity nos lleva a recordar directamente al joven Eric Draven (un atlético Brandon Lee que murió misteriosamente durante el rodaje). También son claras las influencias de Blade (Stephen Norrington, 1997), en la cual Wesley Snipes metido en el papel de un rudo cazavampiros realiza toda una serie de saltos asombrosos de una azotea a otra. No obstante, frente a los antecedentes de esta escena podemos citar no menos alusiones posteriores entre las cuales la más original sea quizás la magistral recreación de Alex de la Iglesia en La Comunidad (2000), donde una asustada Carmen Maura huye por los tejados de los edificios de la Gran Vía madrileña llevando consigo una maleta llena de dinero, y cuyos perseguidores, en vez de unos temibles agentes con gafas negras, resultan ser los miembros de una comunidad de vecinos capaces de cualquier cosa. Una de ellas, Ramona (Terele Pávez), realiza un increíble salto exactamente igual que Trinity (con un plano picado absoluto creado magníficamente por ordenador) pero sustituyendo las brillantes botas negras de la heroína por unas babuchas celestes.

Todo este despliegue de acrobacias y de luchas espectaculares cobran en Matrix un papel fundamental. No olvidemos que los protagonistas se hallan inmersos en un mundo irreal creado por la máquina donde todo es posible, su mente puede deambular por esta realidad alternativa acompañada, no de un cuerpo "real", sino de una imagen proyectada de ese cuerpo que sí está en el mundo real conectado a una máquina con un programa de carga que les permite estar donde y cuando quieran ${ }^{11}$.

\footnotetext{
${ }^{11}$ Este programa de carga que abastece a los rebeldes de cualquier elemento que necesiten para adentrarse en Matrix recuerda a la idea del "constructor universal" de John Von Newmann. Este constructor virtual era una figura que podía reproducir cualquier otra figura o elemento, incluida ella misma. WOOLLEY, B.: op. cit, pág. 64.
} 


\begin{tabular}{|c|c|}
\hline & Chantal Martínez Fernández \\
\hline
\end{tabular}

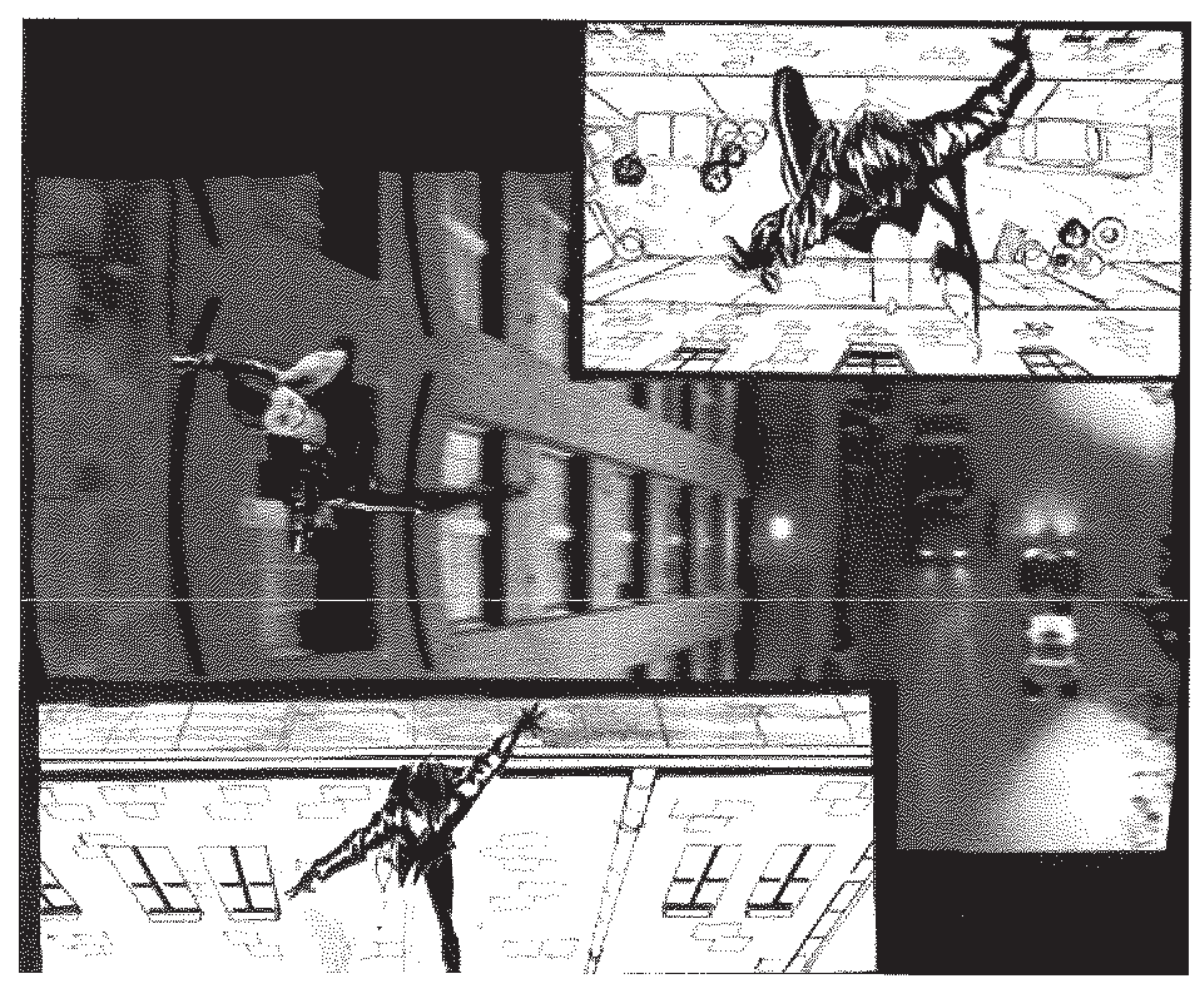

8. Espectacular salto de Trinity en su huida de los agentes. Fotograma y comparación con la escena del story-board (Darrow y Skroce)

Estas luchas fantásticas beben directamente de la influencia de las leyendas tradicionales chinas que narran las maravillosas aventuras de caballeros formados en santuarios remotos capaces de adquirir poderes sobrehumanos que les permite realizar saltos increibles y hasta volar mientras luchan. Estos cuentos populares orientales están fantásticamente recreados en la película Tigre y Dragón (Crouching tiger, hidden dragon, Ang Lee, 2000) y, por supuesto, son la fuente directa de todos los videojuegos y cómics que son fundamentales en la estética de Matrix.

Como es lógico, la profecía del Oráculo respecto al futuro de Trinity se cumple a la perfección. De hecho, es esta fe absoluta en la "divinidad" de Neo la que hace que el joven resucite tras ser tiroteado por el agente Smith. Mientras el cuerpo real de Neo está conectado en la nave a Matrix, Trinity, siempre junto a él, le dice El Oráculo predijo que me enamoraría y que ese hombre que yo amara sería el Elegido. ¿Lo entiendes? No puedes estar muerto. No puedes. Porque es a ti a quien amo. ¿Me oyes?. Te amo. Y ahora, levántate. Cuando Neo alcanza el cénit de su mesianismo 


\section{Q:-vierilos Matrix: las claves de un relato prometeico mesiánico}

\section{Darrow y Skroce:}

Los centinelas.

tras su milagrosa resurrección y acaba con el agente Smith, la nave de Morfeo es atacada por los centinelas, enormes máquinas con forma entre arácnido y cefalópodo que vagan por el subsuelo de las ciudades para acabar con cualquier intruso que amenace el orden del sistema (FiG. 9). La nave de los protagonistas se ve constantemente amenazada por estas máquinas, así que para destruirlas deben activar el P.E.M. (Pulso Electromagnético) que ataca directamente su sistema y las destruye. Sin embargo, al activar este dispositivo la nave queda durante unos minutos sin energía y, por tanto, con los ordenadores apagados. Cuando la mente de Neo se encuentra luchando contra los agentes en Matrix, su cuerpo está en la nave conectado al ordenador. El ataque de los centinelas es ya inminente y, sin embargo, Morfeo no puede activar el P.E.M pues ésto supondría la muerte de nuestro héroe. Trinity, que no se ha apartado del cuerpo de Neo ni un instante, grita su nombre con miedo e impaciencia y cubre con su cuerpo el de su amado justo en el momento en que Morfeo activa el dispositivo. Todo ocurre de manera muy rápida. Sin embargo, la mente de Neo vuelve en el momento preciso y su cuerpo es desconectado rápidamente por Trinity para que no sea destruido. Una vez en la nave, y con todos los circuitos apagados creando así una atmósfera más íntima para la única escena de amor de la película, la pareja se funde en un suave beso. Esta secuencia es un auténtico "salvamento en el último minuto", recurso muy utilizado en el cine desde Griffith, que aporta tensión y dinamismo a la trama.

El plano siguiente se abre con la aparición de los números verdes sobre la pantalla negra. Se trata del ordenador central de Matrix que intenta localizar la llamada de Neo desde una cabina telefónica avisando a los humanos de su misión. Ésta es la escena final de la película en la cual Neo, ataviado con un largo abrigo negro, observa a la multitud de humanos "alienados" que le rodean (comprendiendo la complejidad de la tarea que tiene que llevar a cabo), luego se coloca sus gafas 
negras y mira al cielo. Cuando la cámara sube mostrando una panorámica cenital de la gran ciudad vemos salir, desde algún punto de esa encrucijada de calles, la figura de Neo volando como un superhéroe y haciendo gala de sus poderes mesiánicos.

\section{UN RELATO PROMETEICO: EL HOMBRE ANTE EL REINADO DE LA MÁQUINA. EL NUEVO FRANKENSTEIN.}

Más arriba hemos nombrado a los centinelas, la amenaza más importante para el grupo de rebeldes además de los agentes. Su forma y el lugar donde se mueven, es decir, las cloacas de las umbrías ciudades terrestres, responden claramente a esa estética futurista ciberpunk: cables, tubos de acero y estructuras metálicas conviven conformando un ambiente muy alejado, sin embargo, del brillante y visionario progreso "high-tech"12. Las vistas de las ciudades terrestres tal y como son de verdad, y no en la realidad creada por Matrix, son tan desoladoras como los escenarios de Blade Runner (Ridley Scott, 1982), cuya historia tiene algunas similitudes con la de Matrix pues se trata del mismo argumento prometeico: la creación por parte del hombre de la inteligencia artificial. Pero si en la epopeya de Ridley Scott el poder de las máquinas (replicantes) es aún dominado por el hombre, Matrix va más allá ideando un mundo en el cual la humanidad vive absolutamente sometida, aunque sin saberlo, al poder de la máquina. Otra película donde se nos presenta un futuro apocalíptico es Inteligencia Artificial (Artificial Intelligence, Steven Spielberg, 2001). Spielberg, sobre una idea original de Stanley Kubrick, nos presenta un futuro incierto y no tan lejano en el que el hombre convive con robots de última generación. La trama girará en torno a uno de ellos, David, un niño-robot (Haley Joel Osment) capaz de amar y sentir que se convertirá, gracias a sus recuerdos, en la única fuente de conocimientos de la humanidad extinguida para los extraterrestres.

En cualquiera de estos casos los personajes se mueven en un ambiente opresivo y sombrio. Muchos de estos escenarios parecen seguir de cerca los proyectos utópicos del grupo de arquitectura británico "Archigram", particularmente La ciudad andante (The Walking City) proyectada en 1964 por Ron Herron. No obstante, los diseños de "Archigram" son más optimistas y mucho menos angustiosos. La visión pesimista del futuro que contemplamos en Matrix, tiene su antecedente directo en películas como la ya nombrada Blade Runner ${ }^{13}$, Mad Max (George Miller, 1980) y Terminator (James Cameron, 1984), cuya acción transcurre en una guerra entre el hombre y la máquina. Tampoco podemos olvidar al poeta simbolista belga Emile

\footnotetext{
${ }^{12}$ Un breve repaso por la arquitectura en el cine de ciencia ficción: GARCíA GÓMEZ, F: "La arquitectura en el cine de ciencia ficción", Boletín de Arte, núm. 13-14, Universidad de Málaga, 1992-93.

${ }^{13}$ Esta gran epopeya de Ridley Scott supone una de las visiones cinematográficas más angustiosas y pesimistas sobre el futuro de la humanidad.
} 


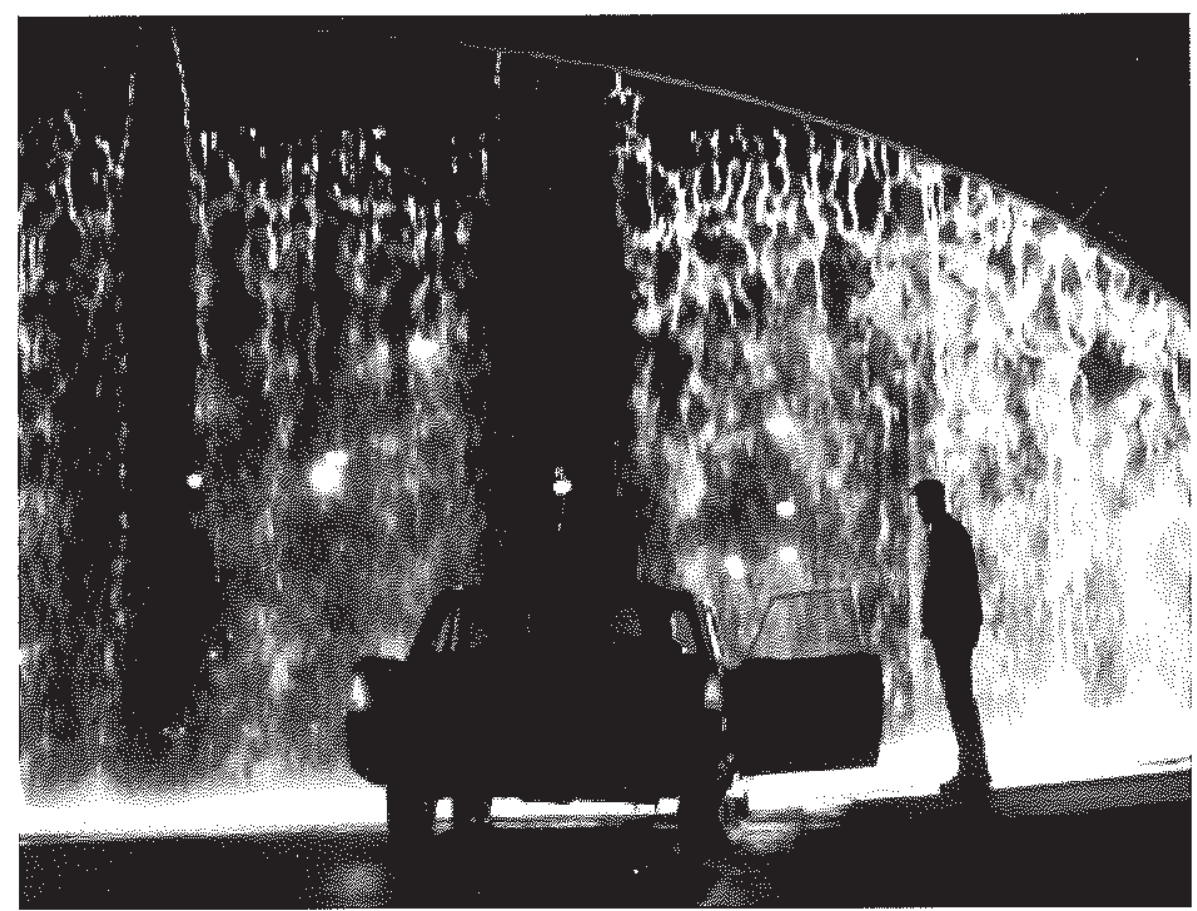

10. La lluvia se convierte en una de las protagonistas cada vez que se muestran imágenes de la ciudad

Verhaeren que a finales del siglo XIX publicó su obra Les villes tentaculères, un auténtico canto a las nuevas y opresivas ciudades industriales.

Es curioso observar la cantidad de planos en los cuales llueve sobre la ciudad (FIG. 10), como también ocurre en Blade Runner. Este rasgo acentúa la sensación de soledad y abatimiento desvelando la temible y oscura realidad. De este modo, la lluvia se convierte en una constante monótona y repetitiva. Cuando Neo es rescatado por Trinity en un coche para llevarlo ante Morfeo, la lluvia cae sobre la ciudad y en su precipitar sobre los cristales del automóvil se asemeja a los códigos de Matrix tal y como se ven en las pantallas de los ordenadores de la nave, así es la realidad sin el "disfraz" con el que se presenta ante los ojos de los humanos. Neo trata de huir pero Trinity y su compañera Interruptor hacen detener el coche y le abren la puerta al joven mostrándole un largo y oscuro camino, esa es la realidad que tan bien conoce y que tan poco le satisface, ellos, sin embargo, le ofrecen una alternativa. A pesar del temor a lo desconocido, Neo acabará aceptando este nuevo rumbo. Al llegar a su destino y, tras ser "desparasitado" durante el trayecto (los agentes le habian introducido un interceptor en el cuerpo para localizarlo), el coche 
se detiene frente a un sobrecogedor edificio modernista que se nos muestra en un impresionante ángulo de encuadre cenital. En este plano la protagonista sigue siendo la lluvia que cae por las cornisas del singular inmueble donde tendrá lugar el primer encuentro entre Neo y Morfeo.

El texto programático de Marinetti y los futuristas titulado El hombre multiplicado y el reinado de la máquina parece casi una premonición del mundo de Matrix ${ }^{14}$. Dice el grupo italiano: "Es preciso reconocer que aspiramos a la formación de un grupo inhumano en el que quedarán abolidos el dolor moral, la ternura y el amor, únicos venenos corrosivos de nuestra potente electricidad fisiológica". "Nuestra potente electricidad fisiológica", ¿acaso no es ésta la función del ser humano dentro de Matrix, ser una mera fuente de energía?. Cuando Morfeo le explica a Neo la terrible realidad le enseña en lo que se ha convertido al hombre: una "pila". Sin embargo, en Matrix, y como un despótico gesto de soberanía, la máquina "crea" un mundo para el hombre en el cual hacer su vida mientras su cuerpo permanece conectado a un enorme ordenador central, la matriz, a la cual le aportan toda la energía necesaria para seguir manteniendo su horrible sistema. De este modo, estamos ante un argumento prometeico en una doble dimensión: primero, la creación de la Inteligencia Artificial por parte del hombre $y$, en segundo lugar, el dominio de la raza humana por parte de la máquina (criatura que destruye a su creador) y la invención de un reflejo del mundo real por parte de ésta para que el hombre habite en él. "El complejo de Frankenstein" o lo que es lo mismo, la rebelión de la máquina contra su creador es un argumento ampliamente tratado en el cine de ciencia ficción ${ }^{15}$. Uno de los primeros ejemplos lo constituye la célebre 2001: Una Odisea en el Espacio (2001: A Space Odyssey, Stanley Kubrick, 1968), en la que el ordenador HAL-9000 asesina a varios de los cosmonautas de la misión a Júpiter cuando sospecha que pretenden desconectarle. Otros muchos títulos han tratado el tema de la rebelión de la máquina de forma más o menos afortunada: Almas de metal (Westworld, Michael Crichton, 1973), Saturno 3 (Stanley Donen, 1980), Tron (Steven Lisberger, 1982) o Asesinos cibernéticos (Screamers, Christian Duquay, 1996). En todos estos casos la dificultad de los humanos para derrotar a sus enemigos radica en que la realidad virtual escapa a todo control, de modo que estas máquinas adquieren poderes casi ilimitados: recordemos al maquiavélico Sid 6.7 (Russel Crowe) de Virtuosity (Brett Leonard, 1995).

La máquina ha sido un elemento fundamental para el cine desde sus inicios. Sin embargo, es en este cambio de milenio cuando, gracias a unos avances científicotécnicos vertiginosos, ha tomado el verdadero protagonismo en el ámbito de la ciencia ficción:

\footnotetext{
${ }^{14}$ MARINETTI, F. T.: Manifiestos y textos futuristas, Barcelona, Ediciones del Cotal, 1978.

${ }^{15}$ El mito de Frankenstein ha sido uno de los argumentos fundamentales para el cine desde sus inicios. VEGA RODRíGUEZ, R.: Frankensteiniana: la tragedia del hombre artificial, Madrid, Tecnos, 2002.
} 
La presencia de la máquina en el cine es constante ya desde sus albores y, evidentemente, no es una casualidad. Resultado preeminente de nuestra civilización y símbolo del progreso, la máquina expresa uno de los más antiguos sueños del hombre: poseer un sustituto (esclavo) que haga el trabajo por él. La sublimación de la tecnología reside en el viejo sueño del barón Frankenstein: crear un ser inteligente, dotado de vida, podriamos decir que de alma, subordinado, sin embargo, a la voluntad humana. La concretización de todas estas ideas es el robot. ${ }^{16}$

Sin embargo, el mito del robot ${ }^{17}$ adquiere toda su dimensión cuando se rebela contra el hombre. En esta situación, el hombre-creador se ve absolutamente desbordado por un poder y una inteligencia que él mismo ha otorgado a su "criatura". En el caso de Matrix, el problema es más complejo pues el enemigo no es un solo robot sino la Inteligencia Artificial en su conjunto, la cual ha llegado a dominar el planeta a costa de la energía vital humana. La misión de Neo y su grupo es compleja por la imposibilidad de someter a control a su enemigo. En este sentido, parece que la única solución posible es "despertar" a toda la humanidad y mostrarle un mundo absolutamente caótico e inverosimil pero real.

No obstante, dentro de este desolador panorama queda aún un último reducto verdaderamente humano: la ciudad de Zión, de la que ya hemos hablado, situada cerca del núcleo terrestre. Alí las personas aún nacen de forma natural y se encuentran libres del dominio artificial, siendo la ciudad de nacimiento de los hermanos Tanque y Dozer, los únicos miembros del grupo que nacieron como auténticos humanos y que por lo tanto, a diferencia del resto de sus compañeros, no tienen el cuerpo lleno de enchufes por haber estado conectados a la matriz. Sin embargo, Zion es un germen que puede acabar totalmente con el sistema, por lo que los agentes no pararán de buscar la manera de acceder a ella para destruirla. Y es así como, si de una nueva Numancia o Masada se tratase ${ }^{19}$, la seguridad de Zión debe ser protegida ante todo por parte de los miembros del grupo de Morfeo que, llegado el caso, darían incluso sus vidas antes de entregar este último paraíso humano.

La ciudad de Zión ha de convertirse en el germen de una nueva era para la humanidad, una época en la que el hombre vuelva a ser dueño de sí mismo. Sin embar-

\footnotetext{
${ }^{16}$ BASSA, J. y FREIXAS, R.: El cine de ciencia ficción, Barcelona, Paidós, 1997, págs. 156 y 157.

${ }^{17} \mathrm{El}$ origen de la palabra "robot" se remonta al año 1920 y fue acuñada por el escritor checo Karel Capek en su obra de teatro "R.U.R." ("Rossum's Universal Robots"). Tomó como punto de partida las expresiones "robotnik" que significa "hombre apenado", y "robota", es decir, "servidumbre" o "trabajo forzado". FERNÁNDEZ VALENTÍ, T. y NAVARRO, A. J.: art. cit., pág. 36. ${ }^{18}$ Los habitantes de estas dos ciudades sitiadas por los romanos prefirieron suicidarse antes que entregarse al enemigo. La ciudad celtíbera de Numancia fue asediada durante nueve meses por los ejércitos de Plubio Cornelio Escipión Emiliano en el 133 a.C. Masada se convirtio en otro enclave mítico de resistencia y rebeldía cuando, en el año 73 d. C. y tras la toma de Jerusalén, sus habitantes se negaron a ceder ante el asedio de los ejércitos de Flavio Silva.
} 


\section{Darrow y}

Skroce: Neo

salva a Morfeo

desde un

helicóptero que

pilota Trinity

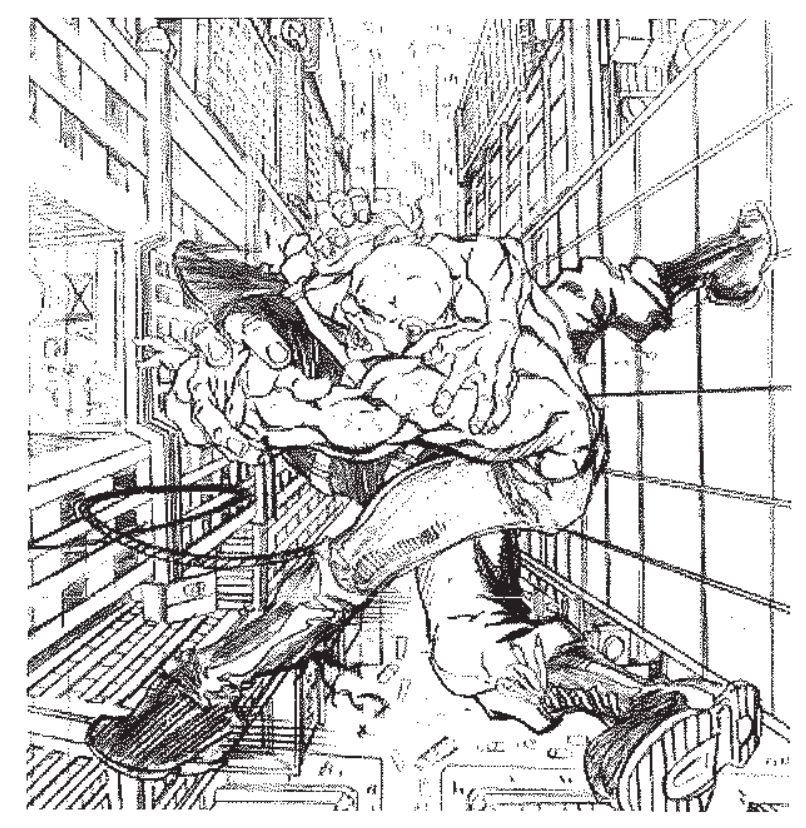

go, esta complicidad y fe en un futuro mejor que caracteriza al grupo no es la que mueve a Cifra, el traidor de esta historia. Este oscuro personaje tiene un pacto con los agentes por el que les entregará a Morfeo para que les desvele los códigos de entrada del ordenador central de Zión a cambio de una vida llena de comodidades en Matrix a pesar de que esta vida sea una simple quimera. En Matrix, como hemos ido viendo, encontramos todos los ingredientes del relato mesiánico: una sociedad oprimida por un tiránico y opresivo poder, un Elegido con su grupo de incondicionales seguidores y, entre ellos, un "judas" que traiciona a este Salvador ${ }^{19}$. Sin embargo, debemos hacer una importante aclaración y es que, si en el relato bíblico, Judas entrega a su maestro (el Mesías), en nuestra historia Cifra traiciona, no a Neo (el "otro" Mesías) sino a Morfeo que, a lo largo de la película nos parece sin duda mucho más "divino" que el propio Neo. Y es que el personaje de Fishburne está lleno de elocuencia y sabiduría, es su fe ciega en un cambio gracias al nuevo mesias la que mueve realmente el argumento y sin la cual los otros miembros del grupo no podrían seguir luchando. El protagonismo de este personaje es tal que Neo comenzará a creer en sí mismo cuando llegue al extremo de tener que poner en juego su vida para salvar la de su mentor (FiG. 11). Morfeo predica la llegada de un Salvador, por lo que su personaje podría relacionarse también con la figura de San Juan Bautista. Paralelismo que se acentua porque es él quien "bautiza" a los humanos que se esca-

\footnotetext{
${ }^{19}$ El tena del traidor ha sido ampliamente tratado en la literatura: BORGES, J. L.: "Tema del traidor y đel héroe", Prosa, Barcelona, Círculo de Lectores, 1975, págs. 328-330.
} 


\section{Cifra traiciona a su grupo a} cambio de una vida tranquila en Matrix

pan del sistema para entrar a formar parte de la resistencia, les otorga una nueva vida comprometida con una dura lucha.

Morfeo y Cifra representan los dos polos opuestos de esta historia, el primero tiene una fe ciega en un futuro mejor, cree sin lugar a dudas que gracias al nuevo Elegido la era de Matrix ha llegado a su fin y que una nueva época verdaderamente humana se abrirá paso. Por su parte, Cifra está cansado de oír

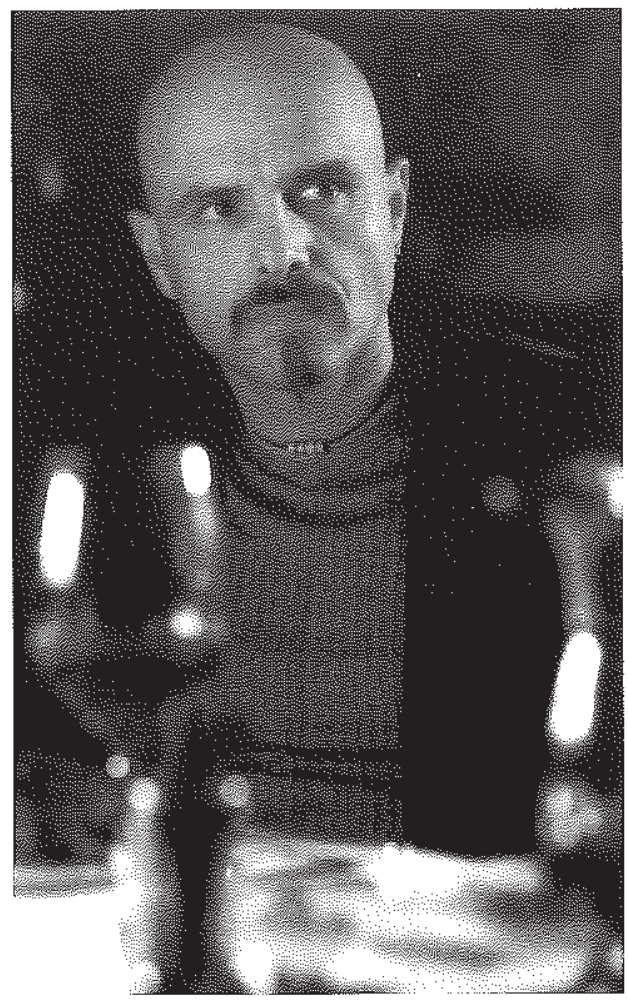
hablar de profecias y elegidos, no le gusta esa lucha incesante por una causa justa llena de penalidades y miserias y lo cambiaría todo por una existencia cómoda e insulsa en Matrix. Su traición no está movida por un acto de rebeldía sino más bien por todo lo contrario, su idea hedonista y cómoda de la vida le hace dar la espalda a todos sus compañeros y entregar a su mentor a manos de la ley a cambio de una vida tranquila dentro del sistema como un humano más. Para él es más feliz el ignorante que vive ajeno a la terrible realidad. Este conformismo de Cifra queda patente en la escena en la que comparte una cena con el agente Smith, nuestro judas saborea un filete y afirma saber que no es real pero que lo prefiere antes que una sacrificada lucha junto a Morfeo y los demás, aún siendo este sacrificio por la liberación de la humanidad (FG. 12). Así pues, Cifra quiere formar parte del sistema, ser una pieza más de su exacto y perfecto engranaje mecánico.

La relación de Cifra y Neo está marcada desde un principio por el recelo y la desconfianza, y es que Cifra no comparte el entusiasmo de Morfeo ante la posibilidad de que el joven sea el Mesías. Todo lo contrario, lo que dice su maestro le parece una absurda y vacua palabrería. En realidad tampoco Neo cree demasiado en sí mismo, pero tanto Morfeo como Trinity le aportan la confianza que necesita para convertirse en el Salvador. Sin embargo, lo que más inquieta a Cifra es la atracción entre Neo y Trinity 
ya que él siente una morbosa obsesión por su compañera. La muerte de este malvado personaje será en manos de Tanque, quien, dolido por el asesinato de sus compañeros de grupo y deseoso de vengar a su hermano, le disparará no sin antes advertirle de que arderá en el infierno (de nuevo una clara alusión a la iconología religiosa).

\section{LA POSTMODERNIDAD CINEMATOGRAFICA. INFLUENCIAS FILOSÓFICAS, ESTÉTICAS Y LITERARIAS: DE LA CITA LITERAL AL PASTICHE}

El concepto de "postmodernidad" surge en los años setenta del siglo XX en forma de debate acerca del mundo del arte, como un cuestionamiento de los logros del Movimiento Moderno y la Vanguardia. La sensibilidad postmoderna tiene en cuenta los fracasos de la modernidad artística y hace nuevas propuestas que pasan por una vuelta "descarada" a la tradición. Cuando hablamos de postmodernidad estamos haciendo alusión a términos como cita, hibridación genérica, intertextualidad, eclecticismo o pastiche. La postmodernidad artistica está marcada por la fragmentación y por un doble código de expresión, es decir, la mezcla de referencias cultas y populares en una misma obra. En el campo cinematográfico la postmodernidad se caracteriza además por las referencias a la propia historia del cine, utilizando una gran variedad de fuentes de inspiración sin ningún tipo de pretensión intelectual o moralizante, incluso, sin tomarse muy en serio a sí mismo. Una gran parte de la producción cinematográfica de las dos últimas décadas hace gala de estas características de la postmodernidad y Matrix es un magnífico ejemplo de ello ${ }^{20}$. A continuación, sin afán de exhaustividad, pasaremos a citar algunas de las múltiples fuentes que configuran el universo de Matrix.

Las teorias psicoanalistas de Jacques Lacan son, sin duda, una de las referencias más claras del argumento. De hecho, Lacan ya habia tratado el tema del ordenador y su poder en la psicosis humana: Si existe algo que presenta un saber independiente del sujeto $y$ que existe en lo real es esa figura moderna: la computadora. La ciencia hace algo por la psicosis, le garantiza que no es un sueño ${ }^{21}$. En esta cita ya vemos uno de los conceptos clave del pensamiento lacaniano que es también uno de los pilares que sustentan la historia creada por los Wachowski: lo real. De hecho uno de los logros de Jacques Lacan, en esa exploración del hombre en toda su complejidad ${ }^{22}$, es la definición de lo simbólico, lo imaginario y lo real. Dada

\footnotetext{
${ }^{210}$ Destacamos dos estudios que tratan algunos aspectos del cine postmoderno: SÁNCHEZBIOSCA, V: Una cultura de la fragmentación. Pastiche, relato y cuerpo en el cine y la televisión, Valencia, Filmoteca Generalitat Valenciana, 1995 y STAM, R., BURGOYNE, R. y FLITTERMANLEWIS, S.: Nuevos conceptos de la teoría del cine, Barcelona, Paidós, 1999.

${ }^{21}$ MILLER, J. A.: Elucidación de Lacan. Charlas brasileñas, Barcelona, Eol-Paidós, 1998, pág. 91.

22 Thomas Mann definiría a Lacan como un explorador de las profundidades del alma. MANN.

T: Freud et la pensée moderne, Paris, Aubier-Flammarion, 1970, pág. 115.
} 
la claridad de la explicación de la teoría lacaniana, hemos optado por reproducir integramente este texto de Elisabeth Roudinesco ${ }^{23}$ :

Bajo la categoria de lo simbólico, Lacan hacia entrar toda la refundición sacada del sistema levistraussiano: "el inconsciente freudiano era pensado de nuevo como el lugar de una mediación comparable a la del significante en el registro de la lengua". Bajo la categoria de lo imaginario se situaban todos los fenómenos ligados a la construcción del yo: captación, anticipación, ilusión. Finalmente, bajo la categoria de lo real se introducía lo que Freud habia llamado realidad psíquica, es decir, el deseo inconsciente y sus fantasías conexas. Según Freud, esa realidad presenta una coherencia comparable a la realidad material y, de hecho, toma el valor de una realidad exterior, hasta el punto por lo demás de tomar su lugar.

Más tarde, y gracias a las influencias de George Bataille, Lacan añadiría al concepto freudiano de "realidad psíquica" una idea de morbidez, de "resto" o de "parte maldita", un componente totalmente matérico y residual que escapa a la razón ${ }^{24}$. Y es precisamente esta concepción de lo real la que aparece en Matrix: un mundo imaginario proyectado por la Máquina que es, sin embargo, percibido como "real" por los humanos que viven ajenos a la verdad. Sin embargo, todo lo subjetivo de las teorías freudianas desaparece al entrar en juego la realidad material: un angustioso desierto (Bienvenido al desierto de lo real le dirá Morfeo a Neo cuando le explica qué es Matrix). "La parte maldita" a la que hacía referencia Lacan se manifiesta de forma totalmente implacable en las secuencias donde podemos ver la auténtica realidad que, sólo los humanos rebeldes conocen. De este modo, la gran duda existencial de los personajes que conocen la existencia de lo real, es elegir entre ésta o el anestésico mundo imaginario creado por Matrix.

Matrix está muy en la línea del Expresionismo alemán pues encontramos claras influencias de la literatura germánica de principios del siglo XX. Podemos hablar de la novela Die Andere Seite (La otra parte) ${ }^{25}$ del checo Alfred Kubin que narra la historia de una ciudad irreal, Perla, gobernada por un soberano invisible llamado Patera el cual dota a los habitantes de todo lo que necesitan, tanto lo material como lo inmaterial, sin embargo, las condiciones en las que vive la población son irreales y sus vidas sólo son aparentes. En esta obra, Patera funciona como un demiurgo que crea el mundo a partir de su fantasía para luego reducirlo a la nada. Matrix es también un mundo irreal como Perla creado por la máquina que, a su vez habia sido creada por el hombre. La idea de una existencia irreal, un espejismo en el cual se mueven las personas pone

\footnotetext{
${ }^{23}$ ROUDINESCO, E.: Jacques Lacan. Esbozo de una vida, historia de un sistema de pensamiento, Barcelona, Anagrama, 1995, pág. 319.

${ }^{24}$ Idem.

${ }^{25}$ KUBIN, A.: La otra parte, Barcelona, Labor, 1974.
} 
en conexión la ciudad de Perla con el mundo de Matrix. Sin embargo, en la historia de los hermanos Wachowski ha desaparecido ese componente onírico y fantástico que Kubin habia heredado del decadentismo finisecular.

También podemos hablar de la obra y el pensamiento de Franz Kafka, que convirtió la literatura en la única razón de su existencia, una vida marcada por un absoluto nihilismo y angustia existencial que fue acentuándose cada vez más. Ya en su primera novela, América, el entusiasmo inicial y la fe en una nueva sociedad moderna alejada de la vieja Europa son sustituidas al final de sus páginas por una dura crítica a la uniformidad y a la mecanización. En La metamorfósis su protagonista, Gregor Samsa, se ha interpretado como una auténtica personificación del propio Kafka (sólo hay que observar la similitud fonética: Franz Kafka-Gregor Samsa). El terror metafísico y la soledad del hombre ante un mundo hostil son dos rasgos fundamentales de la angustia kafkiana que vemos plenamente representados en Matrix. Por supuesto, no en todos los hombres que viven ajenos a la verdadera y temible realidad, sino en el grupo de rebeldes que luchan contra el sistema. Comparte particularmente este carácter de los personajes kafkianos la figura de Morfeo que, no obstante, y como todos los personajes del escritor checo, no pierde jamás la esperanza pese a que las condiciones sean extremas. Además, sus personajes suelen hacer un esfuerzo heroico, a veces por encima de sus posibilidades, hacia la redención. Este es quizás el rasgo que mejor define a $\mathrm{Neo}$, el cual arriesga su vida para salvar la de su maestro aún habiendo sido advertido por el Oráculo de que no es el Elegido (su heroica acción demostrará que sí lo es pues él mismo se concienciará de su divinidad haciéndose indestructible).

Otro elemento kafkiano que aparece claramente en el film es el despertar. Éste toma un sentido simbólico como toma de conciencia de la vida y conlleva además una interrogación acerca del sentido de la existencia. En Matrix este despertar marca la diferencia entre los humanos libres y el resto, es decir, los que se encuentran conectados al ordenador central, la matriz, al que alimentan con su energía vital mientras sus mentes vagan por una falsa realidad. Todos los miembros del grupo han pasado por la terrible experiencia de este despertar que aparece en la película sólo una vez en el caso de Neo. El cuerpo humano dentro de una cápsula llena de un viscoso líquido, se asemeja a una masa rosada e informe de carne o a un feto dentro de la placenta materna, pero en vez de un solo cordón umbilical su cuerpo está lleno de cables, tubos y válvulas que lo unen al sistema central. No se acaban aquí las similitudes con el expresionismo alemán, en este caso pictórico, pues en el story-board de la película esta escena se nos muestra mucho más sobrecogedora y violenta (FiG. 13). Aquí la figura de Neo aparece claramente distorsionada con una estilización muy semejante a la que utilizaba Munch especialmente en su obra El grito, donde todo el paisaje se deforma y cobra movimiento gritando junto al personaje central en una clara y desesperada expresión del vacío y la angustia. 
13. Darrow y Skroce: Neo es rescatado de "la matriz"

Quizás mucho más surrealista que expresionista sea la escena del confesionario, sin duda una de las más originales del film. Neo es apresado por los agentes y llevado a una pequeña y opresiva habitación. La sensación claustrofóbica se acentúa gracias al ángulo de encuadre: mientras Neo aparece sentado ante una mesa en una de las esquinas de la habitación, la

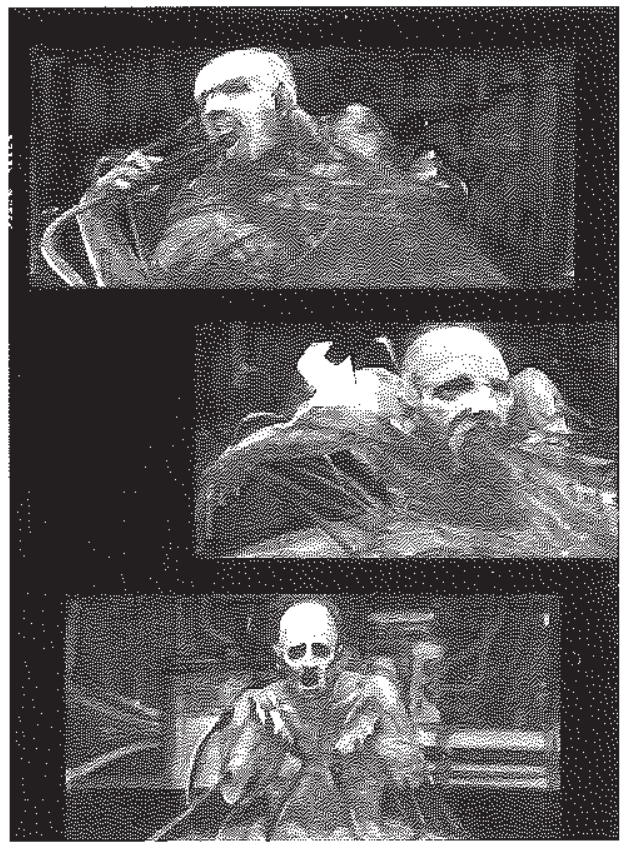
cámara realiza una panorámica desde un ángulo picado empequeñeciendo y acentuando la indefensión del protagonista. El color predominante en esta escena es el verde $y$, sin embargo, no se trata de una tonalidad tranquilizadora 0 , como tradicionalmente se interpreta, símbolo de esperanza. Muy al contrario, toda esta gama de verdes desde las paredes hasta la carpeta donde se guarda el expediente de Neo, pasando por la fría luz, adquieren un valor angustioso y opresivo configurando una atmósfera desagradable y artificial. En este lugar Neo es interrogado por el agente Smith el cual parece saber cada uno de sus movimientos. En una carpeta guarda su doble expediente: por un lado el de Thomas A. Anderson y por otro, el de Neo el pirata informático. Smith le ofrece hacer tabula rasa con todos sus delitos informáticos a cambio de que le ayude a encontrar a Morfeo, de quien habla como de un peligroso terrorista.

Sin embargo, Neo no está dispuesto a ayudarle y le pide hacer una llamada. Es entonces cuando el agente le advierte que para qué va a hacer una llamada si no puede hablar. Neo queda algo confuso ante estas palabras e inmediatamente su boca comienza a desaparecer. La ausencia de boca en un personaje fue un recurso muy utilizado por Magritte para crear un mundo extraño donde la impotencia y la anulación del "yo" se manifiestan a la perfección. Además, esta impactante escena nos remite en seguida a otra de la película Un perro andaluz (Un chien andalou, Luis Buñuel, 1929), donde el protagonista también aparece sin boca, pero en este caso la imposibilidad de hablar o actuar viene condicionada por la frustración del personaje ante la dificultad de poseer sexualmente a su compañera. Los tintes irónicos y auténticamente surrealistas 
vienen marcados por la aparición del vello de la axila de la mujer (aunque también puede ser identificado como vello púbico con connotaciones claramente sexuales) en el espacio liso que ha dejado la boca en la cara del hombre. Sin embargo, en Matrix esta ausencia de boca puede identificarse con la impotencia del hombre ante un mundo que lo oprime; la rebeldía de Neo por escapar del rígido sistema determina finalmente esta situación. Como en la Metamorfosis de Kafka, el protagonista se ve imposibilitado a actuar y siquiera a hablar y así queda totalmente indefenso y a merced de una fuerza superior que lo domina. En el caso kafkiano esta figura opresora es la del padre que adquirirá toda su terrible dimensión cuando Gregor Samsa se transforme en un insignificante insecto. En Matrix el terrible ente dominador no es otro que un sistema preciso y opresivo que somete al ser humano a su voluntad. Poco después, los agentes introducen por el ombligo de Neo un horrible insecto-parásito que funciona como localizador. Sin embargo, la violencia de la escena se ve de súbito detenida cuando suena un despertador y Neo se despierta en su cama asustado y creyendo que todo ha sido un sueño. Después, el protagonista se dará cuenta de que todo lo que ha pasado ha sido real, pues será Trinity, en el camino en coche para ir a su primer encuentro con Morfeo, la que extraiga del cuerpo de Neo el insecto-localizador.

El universo Matrix también le debe mucho a autores como Calderón de la Barca - los místicos San Juan de la Cruz y Santa Teresa de Ávila. En el primer caso, lo que "Matrix" plantea viene a ser la transcripción literal de esa gran propuesta del barroco español, que debemos a Calderón de la Barca: "la vida es sueño". Podemos traducir "sueño" por ilusión o simulacro imaginario, de tal modo que despertar de ese "sueño" es conocer la verdad, entrar en contacto (doloroso y cruel) con lo reaft. En cuanto a las influencias de la Mística, la existecia de una desmaterialización del cuerpo mediante técnicas digitales y una existencia autónoma de la mente en un espacio no real recuerda mucho al éxtasis plotiniano: la fuga de lo sensible a lo intangible ${ }^{27}$. Pero mientras que para los místicos, esta desmaterialización supone un paso más para acercarse a Dios, en Matrix el cuerpo se mantiene preso alimentando con su energía a las máquinas mientras la mente vaga por un universo virtual creado para mantener a la humanidad alienada.

\section{UNOS EFECTOS ESPECIALES REVOLUCIONARIOS}

Matrix es, probablemente, una pelicula que haya que ver más de una vez para comprender su sentido y ahondar en la complejidad de su argumento ${ }^{26}$, y es que la pri-

\footnotetext{
${ }^{26}$ MARTÍN ARIAS, L.: "Matrix: lo semiótico, lo imaginario y lo real", Efecto 2000: lo último en Ciencia Ficción. Filmoteca Escritos-119, Caja España, 2000, pág. 9.

${ }^{27}$ MALDONADO, T.: op. cit., pág. 64.

${ }^{28}$ Se trata de una complejidad relativa. No olvidemos que la película es un magistral ejemplo de postmodernidad, de modo que las citas y alusiones a sus fuentes son absolutamente superficiales.
} 


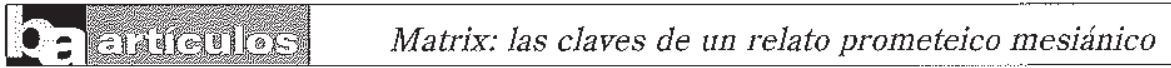

\section{Darrow y Skoce: \\ Construcción del bullet-time (tiempo bala) en el story-board}

mera vez el espectador no puede más que quedarse absolutamente seducido por sus sofisticados efectos especiales. En este estudio hemos intentado ir más allá de una lectura epidérmica. Un análisis técnico y exhaustivo de los efectos especiales empleados sería una materia de estudio interesante y extensa pero no ha sido éste el objeto de este trabajo. No obstante, sí que podemos señalar que Matrix ha marcado un antes y un después en el empleo de los efectos especiales. Basta nombrar dos películas como herederas directas: $E l$ arte de la guerra (The art of war, Christian Duquay, 2000) en la cual los efectos de la cámara Bullet-time (FI. 14) capaz de captar hasta 12.000 fotogramas por minuto, sirve de telón de fondo para un intrépido Wesley Snipes escapando de la mafia japonesa y, por otro lado, Romeo debe morir (Romeo must die, Andrzej Bartkowiak, 2000), donde gracias a unos sofisticadísimos efectos especiales, el productor de Matrix logra hacer algo entretenida esta cinta que narra la historia de Romeo y Julieta pero con la lucha de dos bandos (negros y chinos) que se quieren hacer amos de la ciudad como protagonistas, dejando muy en segundo plano la historia de amor central. Como parodia, hay que destacar Scary Movie (Keenen Ivory Wayans, 2000), donde la protagonista y el asesino en serie enmascarado entam blan una lucha al más puro estilo de Trinity y los agentes en la primera escena de la película, con efectos de cámara ralentizada incluidos.
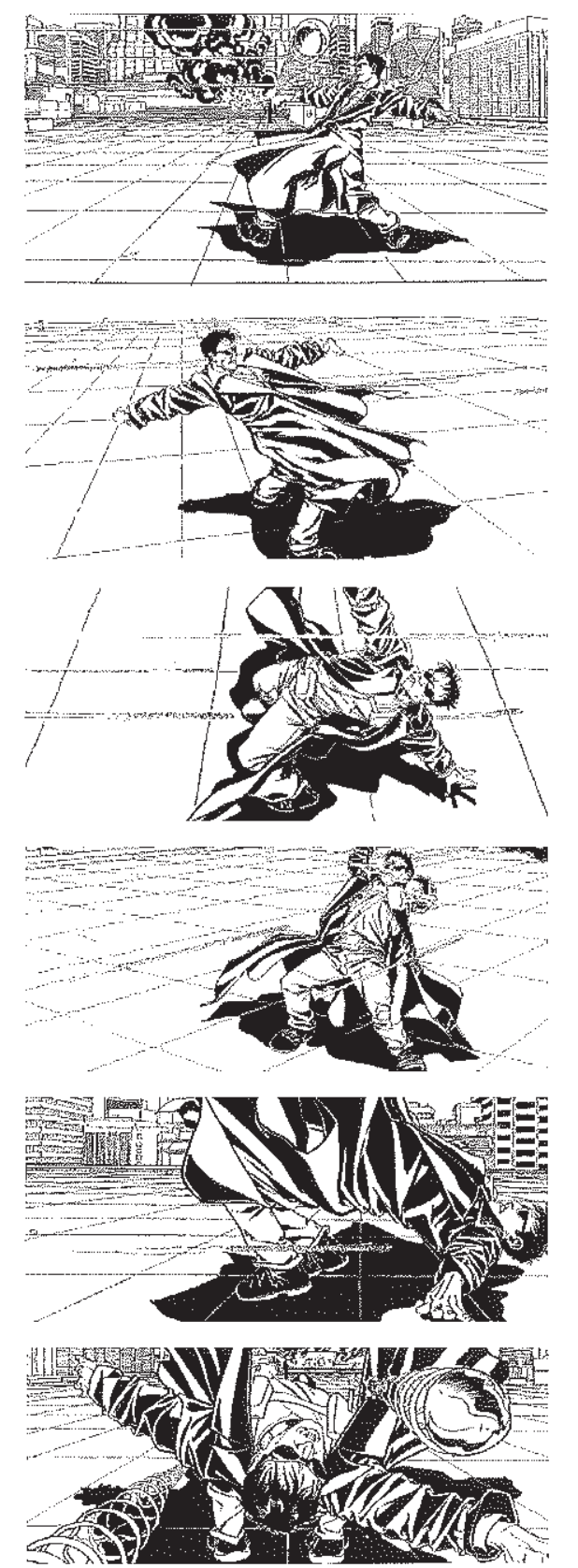
Sin embargo, la influencia de la gran película de los hermanos Wachowski no se limita al ámbito cinematográfico. También la publicidad, como campo experimental por excelencia, ha enriquecido sus recursos expresivos gracias a los descubrimientos de Matrix. Tampoco podemos olvidar la influencia de esta película en el mundo de los videojuegos que constituían, a su vez, una de sus fuentes de inspiración. El videojuego reune el dinamismo del cine, la accesibilidad de la televisión, la fuerza del cómic y sobre todo el poder envolvente de la imaginación, del creador de ilusiones, el jugador ${ }^{29}$. Uno de los primeros en utilizar el bullet-time fue Max Payne (Sam Lake y Petri Järvilehto para Remedy Entertainment, 2001). Y como no hacer alusión al controvertido videoclip Freeek! de George Michael (2002), donde la estética cybernética sirve de fondo para unas escenas muy subidas de tono que provocaron la censura en Hong-Kong y EE.UU. El final está inspirado directamente en el universo de Matrix: un feto dentro de una placenta conectada a unas máquinas con forma de arácnido.

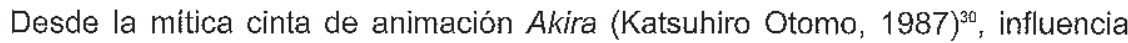
fundamental para los hermanos Wachowski, las aventuras cibernéticas han sido uno de los temas preferidos de la ciencia ficción. Como pionera podemos citar El cortador de césped (The Lawnmower, Brett Leonard, 1992). Aunque quizás la realización más paradigmática de este género y antecedente directo de Matrix es Johnny Mnemonic (Roberto Longo, 1995) protagonizada por el mismo Keanu Reeves que, metido en la piel de un informador del futuro, es perseguido por un grupo de matones que quieren cortarle la cabeza por un exceso de información de vital importancia guardada en su "disco duro" particular.

Parece lógico, pues, que Matrix cerrara un siglo en el cual los avances científicos y técnicos se sucedieron con una rapidez vertiginosa, el siglo donde se inició la era de la informática y la cibernética cuyo final desconocemos aún. De este modo, los hermanos Wachowski nos plantean una cuestión fundamental: ¿a qué conduce esta era absolutamente informatizada?. La RV (Realidad Virtual) representa una especie de nuevo contrato entre humanos y computadoras, un arreglo que podria concedernos un gran poder y tal vez cambiarnos de forma irrevocable en ese proceso ${ }^{31}$.

\footnotetext{
${ }^{29}$ SUÁREZ, G.: "Héroes en el ordenador", El País Semanal, nº 1.386, 2003, pág. 76.

${ }^{30}$ Esta película es todo un hito en el anime japonés (Manga) y una de las fuentes directas de Matrix y de todas aquellas películas y videojuegos de estética ciberpunk (introducción de elementos robóticos en el cuerpo, cables, sensores, interruptores, etc.). En esta metamorfósis del cuerpo en enjenđro mecánico y en la introspección en el stubconsciente humano, hay que destacar la figura de David Cronenberg. Además de crear escuela, su cine ha sido bautizado por la crítica con el sugestivo nombre de "cine de la nueva carne". NAVARRO, A. J. (ed.): La nueva carne. Una estética perversa del cuerpo, Barcelona, Festival de Sitges-Valdemar, 2002. ${ }^{31}$ RHEINGOLD, H.: Realidad Virtual, Barcelona, Gedisa, 1994, pág. 401.
} 
Para muchos esta película es un ejemplo más dentro de la larga lista de la ciencia ficción. Para otros Matrix es una verdadera película de culto que ha revolucionado con sus efectos especiales la industria del cine. Por mi parte, la considero un verdadero halago a la postmodernidad cinematográfica con influencias tan diversas como el western, la serie B o las aventuras tradicionales de capa y espada pasando, como hemos analizado en este trabajo, por multitud de influencias religiosas, filosóficas y mitológicas. Un film de continuidad narrativa y, por supuesto, eminentemente comercial que, sin embargo, esconde muchos valores más allá de esa primera visión en la cual no podemos ir más allá del impacto producido por sus efectos especiales.

Llegados a este punto quizás sea importante concluir diciendo que Matrix es una película novedosa y, no sólo en lo que se refiere a sus efectos especiales, pues lo que realmente vemos en esta gran epopeya es que, en la era de la Internet y los avances cibertécnicos, el ser humano como creador se ve llevado hasta el límite más dramático en la relación con su "criatura" la cual to ha dominado y sometido completamente. En este angustioso panorama, sólo la intercesión de un Mesías liberador podrá salvar al mundo de su caótico destino. Un verdadero canto a la espiritualidad y a la vuelta a unos valores y creencias profundos en un mundo como el nuestro, inmerso en una actividad frenética y cambiante a causa de los medios de masas y la era digital. Se trata de una espiritualidad un poco - por emplear un término coloquial- "de andar por casa", es cierto. Además, sus múltiples influencias y citas producen un efecto absolutamente ecléctico y pastichero. Sin embargo, Larry y Andy Wachowski han ideado un mundo en el que el hombre moderno, como creador, se cuestiona a sí mismo. También han resucitado muchos mitos y alusiones a la religión que permanecían aletargados en el subconsciente colectivo. Y no cabe duda que la puesta es escena es absolutamente excepcional.

Resulta paradójico, sin embargo, que para resucitar unos valores espirituales en el hombre moderno, Matrix emplee como recurso fundamental los efectos especiales y los avances informáticos más vanguardistas, quizás para constatar hasta que punto podemos llegar a depender de este "monstruo" que hemos creado ${ }^{32}$.

\footnotetext{
${ }^{32}$ Lo que se prođuce en Matrix es una mezcla entre crítica y fascinación por la Máquina y la creación de vida artificial. Como advierte Francisco García Gómez sobre Metrópolis (Lang, 1926): debemos reseñar una dualidad constante a lo largo de toda la película: la vida futura y el progreso tecnológico provocan a la vez fascinación y rechazo moral. GARCíA GÓMEZ, E: op. cit., pág. 364.
} 
MATRIX (THE MATRIX), 1999

DIRECCIÓN: Andy y Larry Wachowski.

PRoducción: Silver Pictures para Warner Bros.

PRODUCTOR: Joel Silver. Guión: Larry y Andy Wachowski.

Fotografia: Bill Pope.

MúsICA: Don Davis.

MONTAJE: Zach Staenberg.

DURACIÓN: 115 minutos.

INTÉRPRETES: Keanu Reeves (Neo), Laurence Fishburne (Morfeo), Carrie-Anne Moss (Trinity), Hugo Weaving (Agente Smith), Joe Pantoliano (Cifra), Gloria Foster (Oráculo). 